\title{
Prevalence, determination, and control of histamine formation in food concerning food safety aspect
}

\author{
Thi-Van Nguyen ${ }^{1,2}$, Le Thanh Do ${ }^{3}$, Hoang Van Chuyen ${ }^{4 *}$ \\ ${ }^{1}$ Faculty of Agriculture and Forestry, Tay Nguyen University, 567 Le Duan, Buon Ma Thuot, Daklak 63000, Vietnam; \\ ${ }^{2}$ School of Land and Food, University of Tasmania, Sandy Bay Campus, Hobart, Tasmania 7005, Australia; ${ }^{3}$ Institute for \\ Global Health Innovations, Duy Tan University, Da Nang 550000, Vietnam; ${ }^{4}$ Faculty of Food Science and Technology, Thu \\ Dau Mot University, Binh Duong Province, Vietnam
}

*Corresponding author: Hoang Van Chuyen, Faculty of Food Science and Technology, Thu Dau Mot University, Binh Duong Province, Vietnam. E-mail: hoangvanchuyen@tdmu.edu.vn

Submitted:31 January 2021; Accepted: 7 May 2021; Published: 11 June 2021

(c) 2021 Codon Publications

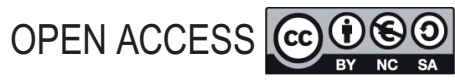

REVIEW ARTICLE

\begin{abstract}
Histamine is a toxic metabolite produced in foods containing a high level of free histidine. This compound can be present in various food sources, especially seafood, dairy products, and fermented foods. Histamine poisoning is one of the most common health risks caused by consuming spoiled foods or improper processed and stored foods. This food poisoning usually causes mild symptoms with higher recovery rates, so people underestimate this hazard. Thus, understanding histamine formation food sources with a high risk for this poisonous agent is critical in improving the awareness of this hazard for food producers and consumers. To avoid histamine-associated food poisoning, the development of control solutions to minimize the formation of histamine and the sufficient detection methods to examine the content of this metabolite in food products are vital. In addition to quality control application and hazards management programs in food processing, the appropriate food regulations identifying the precise limit of histamine in foods are essential for preventing this poisoning from occurring in the food supply chain. This review discusses the prevalence, control strategies, detection techniques, and regulations related to histamine hazards in foods.
\end{abstract}

Keywords: control; detection; food safety; formation; histamine; poisoning

\section{Introduction}

Histamine (HA) is a biogenic amine, water-soluble, nitrogenous, and polar substance found in nature and the human body (Smith, 1981; Figure 1). This compound regulates specific functions related to the human immune, nervous, and intestinal systems. It is also defined as a toxic agent for human health if ingested (Colombo et al., 2018). HA poisoning has been recognized as a foodborne hazard, mainly related to seafood and dairy product consumption (Comas-Basté et al., 2019; Taylor, 1985). It is a metabolite product produced from histidine by the bacterial enzyme called histidine decarboxylase (Chin et al., 1989). The produced HA eventually accumulates and diffuses into the internal parts of foods, and its excess concentration may result in poisoning for consumers (Tao et al., 2009). Moreover, HAis also recognized as an indicator of food quality in quality assurance programs (Dasgupta, 2020; Kerr et al., 2002).<smiles>NCCc1c[nH]cn1</smiles>

Figure 1. The structural formula of HA with an imidazole ring (Smith, 1981). 
Many studies have reported the HA poisoning derived from spoiled foods, their relationship between food processing and storage practices, and HA formation (Dasgupta, 2020; Kerr et al., 2002; Velut et al., 2019; Visciano et al., 2014). The first event of HA hazards was reported in 1799 in Britain (Taylor, 1985). However, the FDA recognized it as a foodborne disease in 1828 and was linked to seafood consumption (Pan and James, 1985). HA poisoning type is a mild disease and is misdiagnosed as an allergy occasionally, (Hajeb and Selamat, 2012). In clinical diagnosis, its symptoms are similar to Salmonella infection or food allergies, such as skin itching, rashes, swelling, and flushing (Taylor, 1985; Taylor et al., 1989). However, recent research has well-documented their symptom characteristics (Chaidoutis et al., 2019). Excessive HA production was primarily associated with the Scombridae fish family (Bartholomew et al., 1987). To date, HA poisoning has also been reported to relate to the Clupeidae fish family and other food sources such as cheese (FAO/WHO, 2018; Møller et al., 2020; Prabhakar et al., 2020; Taylor, 1985).

Foodborne outbreaks are pivotal for both food authorities and producers if control measures and legislation are insufficient to minimize this hazard (EFSA, 2018; FAO/ WHO, 2018; Feng et al., 2016). Fully understanding and evaluating this hazard is necessary to improve food production practices. Many HA poisoning cases have not been recorded because of mild symptoms, and the higher recovery rate has made people underestimate this risk (FAO/WHO, 2018). Besides fish products, other food sources could also be potential sources of HA formation (Colombo et al., 2018). Control and prevention strategies should be regulated and applied in the food supply chain. Precise data on regulatory limits of HA present in all food types apart from the existing seafood products needs to be identified and listed. This review article focuses on HA hazards present in foods. It primarily emphasizes on aspects of HA prevalence, detection, control measures, and regulations.

Although several review articles related to HA in seafood products have been published, only a few considered the mechanisms of HA formation in foods. Some others reported relevant outbreaks in recent years and the rapid methods for HA detection (Visciano, 2020). There has been limited information on the prevalence of HA in various food sources besides fish and fishery products. Thus, this review aims to discuss the HA formation associated with various types of food like meat, seafood, dairy, and vegetable products. The relevant food regulations applied in different regions will also be reviewed and confirmed with updated information. In addition, a summary of the conventional and newly developed HA detection approaches and control measures in research and food industry practices will be mentioned.

\section{Histamine Poisoning Caused by Food Consumption}

\section{Formation and diffusion of HA in foods}

The free histidine-rich foods contain the histidine decarboxylase enzyme. This enzyme in certain environmental conditions converts histidine into $\mathrm{HA}$, which gradually accumulates in the food (Colombo et al., 2018; Figure 2). Ladero et al. (2010) reported the enhancement of HA production because of other biogenic amines. This enhancement resulted from amines that stimulated bacterial activities, thereby increasing HA formation (Dasgupta, 2020; FAO/WHO, 2018).

The microorganism strains that stimulate the HA formation have been studied and well documented in previous studies (Dasgupta, 2020; Durak-Dados et al., 2020; FAO/ WHO, 2018; Tao et al., 2009). Taylor et al. (1989) examined the HA production of 38 bacterial species including 112 strains in tuna fish infusion broth and trypticase-soy broth-histidine media. Superior HA production was observed in Enterobacter aerogenes and Proteus morganii with a concentration up to $200 \mathrm{nmol} / \mathrm{mL}$ of medium. Dominant bacteria species related to HA accumulation belonged to the Enterobacteriaceae family (Taylor et al., 1989; Tsai et al., 2005). The HA-forming strains such as Raoultella planticola, Raoultella ornithinolytica, and Hafnia alvei were also found in tuna sandwich samples (Kung et al., 2010). The Gram-negative bacteria were linked to spoiled seafood. Gram-positive bacteria like Lactobacillus strains are commonly present in fermented products such as kimchi or cheese. Tsai et al. (2005) reported that HA-forming bacteria strains found in half of the kimchi products sold in Taiwan supermarkets were Lactobacillus brevis and L. paracasei. L. buchneri was<smiles>N[C@@H](Cc1c[nH]cn1)C(=O)O</smiles>
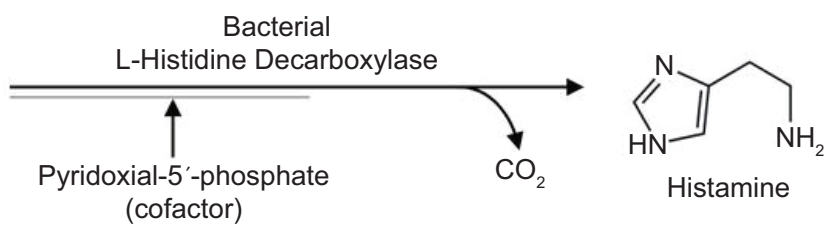

Figure 2. The formation of HA (Comas-Basté et al., 2019). 
isolated from Swiss cheese samples (Sumner et al., 1985). In another study, yeasts including Malaga, Burgundy, and Bordeaux were found to be responsible for HA production in elderberry wine (Pogorzelski, 1992). Hence, these species represent different sources present in food and the surrounding environmental conditions.

Several main factors including environmental, processing, or storage conditions, caused the HA formation within the foodstuff. The primary causes were improper food processing or storing practices because of temperature and time abuses (FAO/WHO, 2018; Kerr et al., 2002; Mercogliano and Santonicola, 2019). The role of the environmental conditions in the biogenic amine formation was first studied on E. faecalis strains. The production of biogenic amines, including HA, was affected by various factors, such as temperature, time, and $\mathrm{pH}$ (Gardini et al., 2001). Temperature abuse during processing and storage was the most common reason leading to HA poisoning outbreaks in seafood consumption (Kerr et al., 2002; Visciano et al., 2014). Among investigated yellowfin tuna samples, the samples stored at $0^{\circ} \mathrm{C}$ accumulated lower HA content than those stored at $8^{\circ} \mathrm{C}$ or $12^{\circ} \mathrm{C}$ at the same storage intervals. Tuna stored at the highest temperature was rejected because of the spoilage and unacceptable sensory quality after only a day (Guizani et al., 2005). Koral et al. (2013) found that low pH could enhance the HA formation based on the observation of higher HA contents in the brined samples with lower $\mathrm{pH}$. Contamination is also considered a crucial factor, causing excessive HA levels in food products. Huss et al. (2000) indicated the importance of controlling the contamination as a significant contribution to HA prevention. In another investigation by Hwang et al. (2011), fish meat samples attained from the factory adhering to the hazard analysis and critical control points (HACCP) program for contamination control were compared with those factory samples without the HACCP program application. The findings revealed that the average HA level in the former group was significantly lower than that in the latter group.

\section{Human health effects of histamine}

HA poisoning associated with food consumption usually causes a mild disease in humans with a quick recovery (Comas-Basté et al., 2020; Schirone et al., 2016). It is previously defined as an allergy case (Ando et al., 2017; Maintz and Novak, 2007). However, recent research clearly showed HA poisoning symptoms belong to food poisoning (Joenputri and Suryana, 2020; Velut et al., 2019). HA could be naturally generated by erroneous and mast cells in the human body (Hungerford, 2010). This substance plays a vital role in controlling the nervous system, neurotransmission, and intestinal system
(Kovacova-Hanuskova et al., 2015). Juhlin and Shelley (1966) observed HA under fluorescence and found it in platelets, gastric mucosa, basophils, blood vessels, and mast cells in the human body. Zeng et al. (2014) evidenced the benefits of appropriate HA release levels to heart failure patients. Excessive HA concentration can cause stimulatory actions of the heart, which results in tachycardia and palpitations (Feng et al., 2016). Symptoms caused by HA poisoning include gastrointestinal symptoms (diarrhea, vomiting, nausea, itching, hypotension, and abdominal cramps) and neurologic symptoms (flushing, tingling, palpitation, or headache). The most typical symptoms are neck, face, and upper trunk flushing (Colombo et al., 2018; Hattori and Seifert, 2017; Taylor, 1985). The outset occurs about 20 minutes after the stale food digestion, and most nonsusceptible patients can recover within 6-8 hours (Feng et al., 2016). Many cases related to this disease may not be sufficiently documented as people can recover after a short period. Thus this poisoning disease need not be considered a public health risk (Chaidoutis et al., 2019). Incidence related to histamine intoxication in EU countries during 2010-2015 is presented in Figure 3 (EFSA, 2017).

HA's toxicology has been described and discussed in a variety of studies including clinical research by DurakDados et al. (2020). Morrow et al. (1991) investigated the characteristics of HA in patients suffering from HA poisoning symptoms. This study confirmed that HA was a toxic agent contributing to poisoning cases. The health effects of HA were linked toits binding to the receptors present on the cell wall membranes. Ijomah et al. (1991) doubted that HA alone was not entirely responsible for food poisoning since significant differences were observed in poisoning symptoms caused because of consuming pure HA compared with those who consumed an equal amount of HA in spoiled fish. A consistent severe result was also found among cases that consumed spoiled fish containing HA, which was in agreement with the study of Lehane and Olley (2000). Del Rio et al. (2017) revealed that HA and tyramine present spontaneously in some fermented foods could enhance the synergistic cytotoxicity towards intestinal cells. The different effects may be caused by other contributing factors along with HA components (Kovacova-Hanuskova et al., 2015). Several biogenic amines such as putrescine or cadaverine are produced in spoiled foods mainly because of enzyme activities occurring in food. The availability of these amines enhanced the elevated HA formation (Chaidoutis et al., 2019).

\section{Histamine intolerance and dose response}

The dose-response level in HA ingestion is inconsistent because of the variation in susceptibility and 


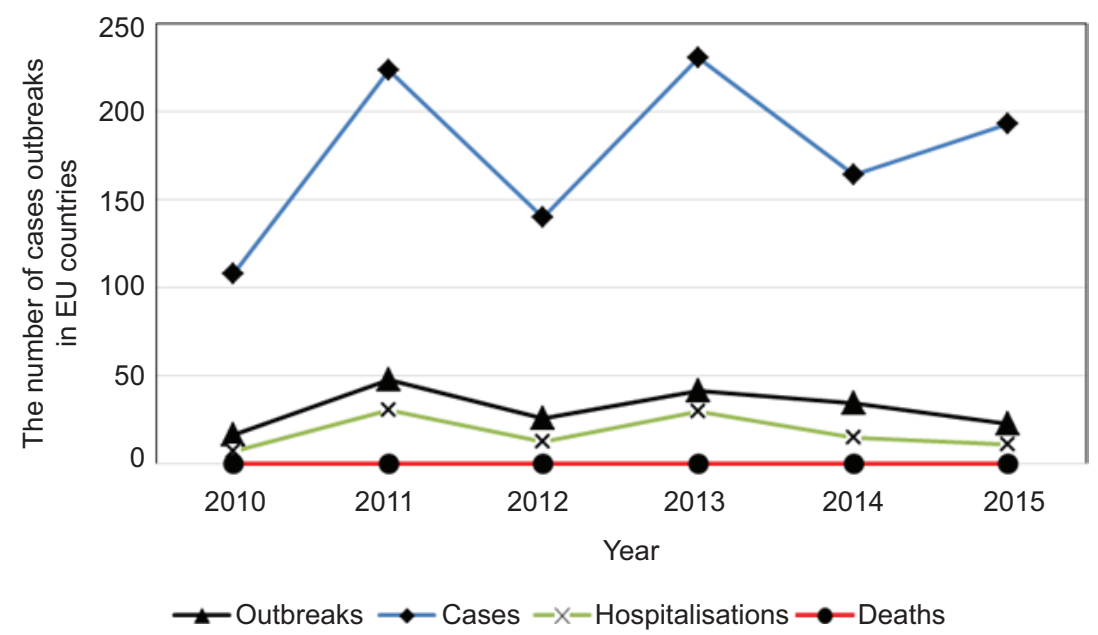

Figure 3. The incidence of histamine intoxication reported in EU countries during 2010-2015 (Adapted from EFSA, 2017).

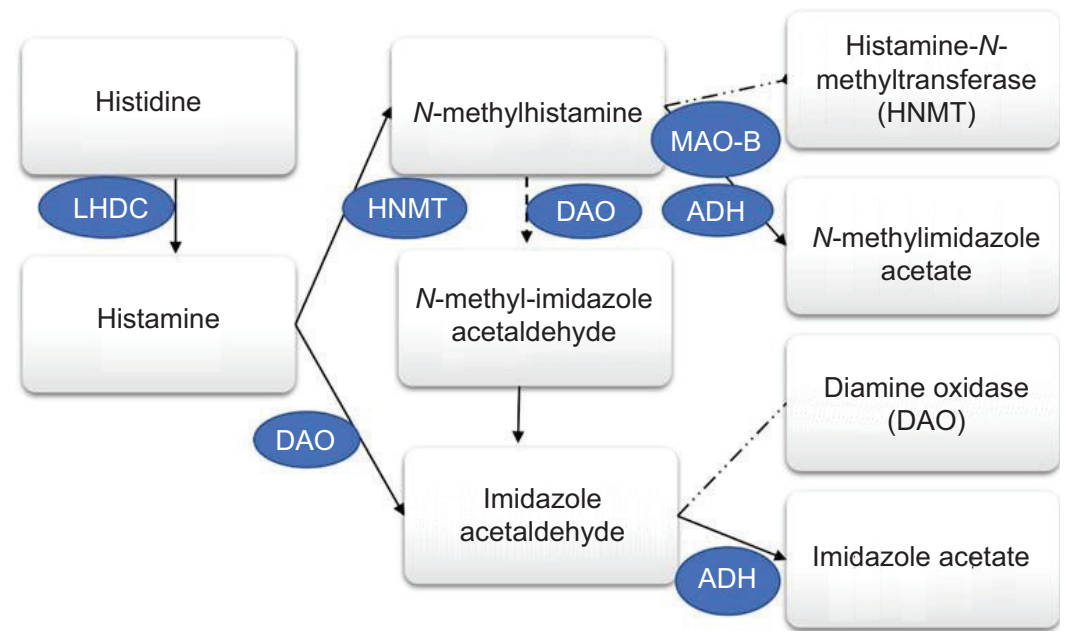

Figure 4. Histamine metabolism involving DAO and HNMT (adapted from Maintz and Novak, 2007). LHDC, L-histidine decarboxylase $\left(\mathrm{H}^{+} \rightarrow \mathrm{CO}_{2}\right)$; HNMT, histamine-N-methyltransferase (S-adenosyl-methionine $\rightarrow$ S-adenosyl homocysteine); MAO-B, monoamine oxidase; ADH, aldehyde dehydrogenase.

characteristics among individuals. Hungerford (2010) discussed the reasons for different HA intolerances. According to him, diamine oxidizes (DAO) is mainly responsible for such differences. Maintz and Novak (2007)reported the mechanism of HA ingesting. They recorded that the toxin could be metabolized by histamine- $N$-methyltransferase (HNMT) via the ring methylation pathway (Figure 4).

Therefore, the intolerance depends on its affinities with these enzymes. Factors impairing enzymatic activities may result in HA overproduction and cause poisoning symptoms to the human body (O'Mahony et al., 2011). The produced HA explained by the pathways of HNMT and DAO in the intestine (Maintz and Novak, 2007) could be converted into an inactive form like acetyl-histamine in the intestinal tract by the enzymatic activities, which was later absorbed into the cell membrane. Accordingly, individual genetic and health status contribute to different HA ingestion responses (Hattori and Seifert, 2017; Lehane and Olley, 2000). The minimum level causing poisoning was reported at $50 \mathrm{mg}$ HA per $100 \mathrm{~g}$ spoiled fish samples by Stommel (2007), while the corresponding levels were $75 \mathrm{mg}$ as recorded in the study of Hungerford (2010).

\section{Foods Associated with HA Formation and Accumulation}

HA is present in different food sources including animals, plants, and microorganisms (EFSA, 2017; DurakDados et al., 2020). The foods associated with this hazard are rich in free histidine (EFSA, 2017; Durak-Dados et al., 2020). Many fish species contain high free histidine. 
Their gills or gastrointestinal tracts naturally have bacteria with the histidine decarboxylase enzyme (EFSA, 2017; Bartholomew et al., 1987; Mercogliano and Santonicola, 2019). Thisbacteria containing HA decarboxylase stimulates HA overproduction (Dasgupta, 2020; Morrow et al., 1991). The decarboxylation bacteria may poison the foodstuff from the environment during harvesting, handling, and storage periods (WHO, 2018; Stommel, 2007; Visciano et al., 2014).

Cheese, beverages, and other fermented foods could be potential sources of HA production (Leuschner et al., 1998; Tsai et al., 2005). Some studies have reported high HA content in fresh meats, fruits, and vegetables (Bodmer et al., 1999). But the association between HA poisoning outbreaks with these sources was uncertain (Ekici and Omer, 2018; Lehane and Olley, 2000). Minimal research reporting this risk in fresh fruits and plants has been studied (Chin et al., 1989; Durak-Dados et al., 2020). In other words, natural HA contents in fresh fruits or vegetables are much lower than the action level causing adverse effects on human health (Comas-Basté et al., 2019). In summary, free histidine content and available carboxylase significantly contribute to HA production in foods.

\section{Fish and other seafood products}

Fresh seafood is reported as the most common HA poisoning and accumulation-causing sources (Chung, 2019; Velut et al., 2019). The fish containing high histidine is scombroid families that include tuna, mackerel, and bonito (Stommel, 2007). Other fish species with Higher HA levels include bluefish, mahi-mahi, marlin, herring, anchovies, pilchards, and sardines (Lehane and Olley, 2000). HA is one of the dominant biogenic amines in many fish species during storage (Hu et al., 2012). Maximum-free histidine content was observed in fresh fish muscles and the decarboxylase bacteria was naturally present in their digestive systems (Mercogliano and Santonicola, 2019). Isolates were obtained from spoiled mackerel and tuna samples, and $31 \%$ of these species produced 0.1 to $4 \mathrm{mg} / \mathrm{mL} \mathrm{HA}$ in the cultural medium broth (Omura et al., 1978). The reaction in which histidine is converted into HA by enzyme activity occurs rapidly at ambient temperature (Auerswald et al., 2006). HA content in $10 \%$ of samples measured in 78 salted fish products purchased from Turkey and Europe was higher than 50ppm, the HA limit level in foods regulated by FDA (FDA, 2011; Koral et al., 2013). Specifically, salted anchovy was detected at the highest level of HA level with $422 \mathrm{ppm}$ by the high-performance liquid chromatography (HPLC) analysis method. Other processed foods, including fish hamburgers, sandwiches, adulteration containing fish, or canned tuna in different regions containing unsafe HA concentrations, were also reported (Durak-Dados et al., 2020; Møller et al., 2020).

Many investigations confirmed the prevalence of HA accumulation in varied seafood of different regions, and scombroid poisoning outbreaks occurred in many countries (Comas-Basté et al., 2020; Chomchai and Chomchai, 2018; Durak-Dados et al., 2020; Kang et al., 2018). In England and Wales, 47 scombroid poisoning outbreaks were reviewed from 1970 to 1979 (WHO, 1982). The Centre for Disease Control (CDC) annual reports recorded 116 outbreaks linked to HA poisoning in America from 1978 to 1982 (Gellert et al., 1992). In Australia, four patients have reported suffering HA poisoning linked to imported canned tuna consumption in Sydney,2015 (FAO/WHO, 2018). On the other hand, 17 samples, including fresh and processed seafood from South African countries, were quantified for HA contents. The finding showed that $6 \%$ of samples exceeding the limit level (50mg/100g; Auerswald et al., 2006).

The study of three rich histidine-containing fish species showed that fresh and salted samples possess low concentrations of HA when compared with smoked and dried samples (more than $50 \mathrm{mg} / 100 \mathrm{~g}$ ). Yellowtail samples were commonly related to the high HA level among fresh samples. In 2011, Tao et al. (2011) surveyed the HA level of samples collected from nine countries. The finding revealed that at least one sample from these countries, excluding Japan, contained HA, and $9 \%$ of samples tested had HA content higher than $50 \mathrm{mg} / \mathrm{kg}$. However, these results are difficult to justify accurately since the statistical data and sample collection method were not analyzed in this study. Similarly, 60 canned tuna fish samples were analyzed for HA contents in Iran between 2012 and 2013 by the enzyme-linked immunosorbent assay (ELISA) method (Khezri et al., 2014). All samples contained $3-383 \mathrm{mg} / 100 \mathrm{~g} \mathrm{HA}$, and $6.67 \%$ of samples had HA levels higher than the regulatory limit level.

An outbreak in San Francisco in 1977 related to sashimi consumption was observed by Lehane and Olley (2000). Suspected samples indicated the presence of spoiled tuna. Another severe outbreak related to tuna consumption containing high HA content was reported in Taiwan in 2008 (Chen et al., 2008). In this outbreak, seven cases of poisoning illness by tuna dumpling consumption. The subsequent investigation showed a high HA concentration of $160.8 \mathrm{mg}$ in $100 \mathrm{~g}$ samples in the suspected samples. Noticeably, even the E. coli count was higher than the regulatory level of food safety with a $50 \mathrm{CFU} / \mathrm{g}$, which provided evidence for the correlation between the contamination level and the HA level of tested samples. Table 1 summarizes some HA poisoning outbreaks related to fish and seafood products in different countries in the last decade. 
Table 1. Histamine poisoning outbreaks reported between 2016-2020.

\begin{tabular}{|c|c|c|c|c|c|}
\hline Number & Associated foods & Number of cases & Location & Year & References \\
\hline 1 & Fresh yellowfin tuna & 40 cases & Reunion Island, France & April 2017 & Velut et al. (2019) \\
\hline 2 & Yellowfin/Ahi Tuna & 50 cases & USA & November 2019 & FDA (2020) \\
\hline 3 & Tuna & 3 cases & France & 2017 & Harmelin et al. (2018) \\
\hline 4 & Butterfish & 27 cases & Valladolid, Spain & July 2013 & Fariñas Cabrero et al. (2015) \\
\hline 5 & Tuna & 2 clusters of people & Netherlands & 2018 & Morroy et al. (2018) \\
\hline 6 & Yellowtail Fish steak & 55 cases & Seoul, Korea & November 2016 & Kang et al. (2018) \\
\hline 7 & Canned sardines & 28 cases & $\begin{array}{l}\text { Vojvodina province, } \\
\text { Northern Serbia }\end{array}$ & January 2014 & Petrovic et al. (2016) \\
\hline 8 & $\begin{array}{l}\text { Fried Japanese Spanish } \\
\text { mackerel fish meats }\end{array}$ & 7 cases & $\begin{array}{l}\text { Hualien County, eastern } \\
\text { Taiwan }\end{array}$ & September 2014 & Hwang et al. (2019) \\
\hline 9 & $\begin{array}{l}\text { Unproperly } \\
\text { refrigerated fish }\end{array}$ & 7 cases & Alaska, USA & May-August 2019 & $\begin{array}{l}\text { McLaughlin and Castrodale } \\
\text { (2019) }\end{array}$ \\
\hline 10 & Tuna salad & 21 cases & Netherlands & 2020 & van Dijken et al. (2020) \\
\hline
\end{tabular}

\section{Cheese and dairy products}

Cheese and other dairy products also contain specific HA contents apart from high proteins ((Joosten, 1988; Joosten and Northolt, 1989; Møller et al., 2020; Taylor, 1985). The prevalence of biogenic amines including HA in cheese is reported in the literature (Comas-Basté et al., 2020; Møller et al., 2020; Taylor, 1985). Because raw milk naturally contains high protein composition including histidine. HA could be produced by enzyme activity during the cheese fermentation process (Ekici and Omer, 2018), and its concentration depends on the type, age, and package of cheese products. The HA content increase with the age of cheese (Şanlı and Şenel, 2015). Fifty-four Chinese meal samples including cheese were analyzed for the HA level in the USA; 863.6 and $107 \mu \mathrm{g} / \mathrm{g}$ HA were detected in blue and parmesan cheese samples, respectively (Chin et al., 1989). However, the detection method used may contain uncertainty factors in the calculation formula for quantification. In another study, the goat cheese was produced by fermenting raw goat milk with Streptococcus faecalis and S. faecium over 91 days ripen process. The later strain is HA decarboxylase strain, which caused the highest concentration of $8.2 \mu \mathrm{g} \mathrm{HA} / \mathrm{g}$ in samples which was much lower than the HA limitation established by EU authorities (200 ppm), and did not perform any risk in consumption related to HA hazard (EU, 2013; Tham et al., 1990).

Microorganism flora in dairy products may contribute to the HA formation. Linares et al. (2011) suggested that HA decarboxylase present in these products mainly belongs to gram-negative bacteria and eukaryotic organism classes. However, Lactobacilli was commonly associated with HA production (Kung et al., 2007; Lehane and Olley, 2000). HA concentration was produced by Lactobacilli (L. buchneri, Leuconostoc, and Lactococcus) at $410 \mathrm{ppm}$ after 3 months of cheese ripening (Joosten and Northolt, 1989). It is noticeable that this cheese was made from pasteurized milk and stater cells. The E. coli indicator of these samples was under an acceptable level of food safety regulation. L. buchneri was also isolated from Swiss cheese samples suspected of causing a small outbreak occurring in 1980 in New Hampshire, USA. This investigation implicated that this strain was strongly associated with the occurrence of HA production of up to $4.07 \mathrm{nmol} / \mathrm{L}$ of MRS broth (Sumner et al., 1985). In miso products obtained from retails in the USA, eight isolate strains produced 10.4 to $39.4 \mathrm{mg} / \mathrm{kg}$ of this toxin in tryptic soy broth. These strains were identified by the polymerase chain reaction method, including Bacillus megaterium, B. subtilis, B. amyloliquefaciens, and Staphylococcus pasteuri (Kung et al., 2007). An effort to detect the presence of histamine-producing species was conducted (Stratton et al., 1992); however, this detection using the leu cocrystal violet method, which did not agree with isolation results in low-salt cheese. Several kinds of cheese, including Gruyere, Gouda, Cheshire, Cheddar, and Swiss, were associated with HA poisoning outbreaks. However, no limit of HA level was established for such food types (EFSA, 2011). There are a limited number of recent studies investigating HA production in dairy samples in the past decade.

\section{Meat and poultry}

Although HA poisoning outbreaks rarely occur with meat or poultry consumption, high HA levels have been detected in these foods too. Vidal-Carou et al. (1990) examined the relationship between HA content and quality of meat during storage. Their findings indicated higher HA levels in spoiled beef and pork meats during the storage period in both cooling and room temperature. 
Besides, HA production in pork samples was faster than that in beef samples in similar storage conditions comparing initial contents (lower $2 \mathrm{ppm}$ ). In this research, HA levels in uncooked samples (0.25-249 ppm) were significantly higher than those in cooked meats $(0.25-3.9$ ppm).

Similarly, the investigation revealed a slight increase in the HA concentration in chicken meat during storage (Silva and Glória, 2002) between 3 and $5^{\circ} \mathrm{C}$ (less than $7.2 \mathrm{ppm}$ ). On the other hand, Masson et al. (1996) compared two species of HA-producing bacteria, mainly Micrococcaceae and Lactobacillus species isolated from meats. Here, HA was detected by HPLC and fluorometric methods. The finding indicated three strains among isolates (94 strains) with the ability of HA production $(2.2$ $\mathrm{mg} / \mathrm{mL}$ ) after 5 days of inoculation.

Fermented sausage samples were analyzed for HA content by Taylor et al. (1978). The level was quantified at low concentration with about $10 \mathrm{ppm}$ on average sausage and salami samples sold in Spani (Dewaal et al., 2006). Turkish fermented sausage was recently defined with HA concentrations ranging from 0 to $469.375 \mathrm{mg} / \mathrm{kg}$ (Ekici and Omer, 2018).

\section{Fruits, vegetables, fermented foods, and other food products}

HA was found in fruits, vegetables, cereal products, and fermented foods (EFSA, 2011; Durak-Dados et al., 2020; Pogorzelski, 1992; Tsai et al., 2005). Significant HA levels were detected in wine, kimchi, and soybean (DurakDados et al., 2020; Mah et al., 2019) by naturally present or added yeast activity during the preparation and fermentation process. According to Pogorzelski (1992), the highest HA production was recorded in Bordeaux yeast among investigated yeasts. However, the level was relatively low, and therefore, the likelihood of outbreak occurrence is not high. The HA determination conducted by the fluorescence method revealed that only 5 in 300 wine samples contained 5-10 mg/L of HA (Ough, 1971).

Canned sauerkraut was also reported to contain a high HA concentration with an average of $4.07 \mathrm{mg} / 100 \mathrm{~g}$ in 10 tested samples (Taylor et al., 1978). Kimchi samples purchased in Taiwan were found to possess $49.8 \mathrm{mg} / 100 \mathrm{~g}$ of HA on average (with the highest concentration recorded at 535 ppm; Tsai et al., 2005) was the first high HA content reported in kimchi products.

Similarly, bacteria producing HA were also investigated in fermented soybean, and the finding revealed high concentrations produced at 500 ppm under 0.5-10\% salt cultural conditions (Tsai et al., 2007). A recent report showed that a 15-month-old baby was suffering HA intolerance because of eating strawberries containing HA (Ibranji et al., 2015). However, research published until now may not fully cover the importance and significance of this emerging foodborne hazard in such fermented products (Durak-Dados et al., 2020; Konakovsky et al., 2011; Kovacova-Hanuskova et al., 2015).

\section{Legislation and Regulations}

The commonly accepted HA level in food is lower than $50 \mathrm{ppm}$ in healthy people. The evidence from some studies showed that consuming over $50 \mathrm{mg}$ of this toxin could cause health effects for the human body. So this level can be examined as "no observed adverse effect level" (NOAEL; Visciano et al., 2014). The maximum limits of this toxin in foods vary from region to region and for different food sources. According to European Commission Regulation (EC No 2073/2005/EC), The accepted HA level in raw fishes and processed fishery products, except fermented produced or fish sauce, is 100-200 ppm. However, amended European (EU) Commission Regulation No 1019/2013 accepts 200-400 ppm for the same food group and 400 ppm for fermented fish products(EU Commission Regulation, 2013). Hence food batches with higher than 400 ppm will be considered unsatisfactory for consumption in the EU(EFSA, 2011) when analyzed by the HPLC method.

In USA, the maximum legal HA level established by FDA is much lower than that in EU countries. Fishery products with HA levels higher than 50 ppm are not permitted for distribution and consumption in the US markets (FDA, 2020). The Canadian government in 2018 set 100 or $200 \mathrm{ppm}$ in the foodstuff as HA limitations for pastes, fermented fish sauces, and anchovies or other fishery products, respectively. In Australia and New Zealand, a maximum level of 200 ppm of HA in fishery foods has been established by the Australian Food Standards Code (FSANZ, 2009; 2016). The HA limitations have also been reported in some Asian countries such as China and Korea (Table 2). Although the Food Safety Basic Act (Act No.48 of 2003) mentioned HA as a critical hazard in the imported food processing practice, the data for Japan is unavailable (Table 2).

\section{Histamine Detection Methods}

\section{Chromatography techniques}

Chromatography approaches for HA detection have been developed since the early stages. The fluorescence chromatography targeted the HA's imidazole ring characteristic to generate chromophores for visualization under 
Table 2. HA limitations established by regulatory authorities or international agencies for food products of different regions.

\begin{tabular}{|c|c|c|c|c|c|}
\hline Authorities/ agencies or regulations & $\begin{array}{l}\text { Countries/ } \\
\text { regions }\end{array}$ & Food associated & $\begin{array}{l}\text { Limits } \\
\text { (ppm) }\end{array}$ & $\begin{array}{l}\text { Issued } \\
\text { year }\end{array}$ & Reference \\
\hline $\begin{array}{l}\text { European Commission Regulation No } \\
\text { 1019/2013 }\end{array}$ & EU & $\begin{array}{l}\text { Fishery products, except } \\
\text { fermented products }\end{array}$ & $200-400$ & 2013 & $\begin{array}{l}\text { EU Commission } \\
\text { Regulation (2013) }\end{array}$ \\
\hline $\begin{array}{l}\text { European Commission Regulation No } \\
\text { 1019/2013 }\end{array}$ & EU & $\begin{array}{l}\text { Processed fish species } \\
\text { associated with a high amount } \\
\text { of histidine }\end{array}$ & 400 & 2013 & $\begin{array}{l}\text { EU Commission } \\
\text { Regulation (2013) }\end{array}$ \\
\hline $\begin{array}{l}\text { Joint FAO/WHO Food Standards Programme } \\
\text { Codex Alimentarius Commission } 2013\end{array}$ & Worldwide & Fish and fish products & 200 & 2012 & FAO/WHO (2018) \\
\hline $\begin{array}{l}\text { USFDA, FDA and EPA Safety Levels in } \\
\text { Regulations }\end{array}$ & USA & $\begin{array}{l}\text { Fishery products, decomposed } \\
\text { fish }\end{array}$ & 50 & & $\begin{array}{l}\text { Visciano et al. } \\
\text { (2020), FDA (2019) }\end{array}$ \\
\hline $\begin{array}{l}\text { Health Canada and the Canadian Food } \\
\text { Inspection Agency }\end{array}$ & Canada & $\begin{array}{l}\text { Anchovies, fermented fish } \\
\text { sauces and pastes }\end{array}$ & 200 & 2012 & FAO/WHO (2018) \\
\hline $\begin{array}{l}\text { Health Canada and the Canadian Food } \\
\text { Inspection Agency }\end{array}$ & Canada & Other fish and fish products & 100 & 2012 & FAO/WHO (2018) \\
\hline $\begin{array}{l}\text { Russian Federation, } \\
\text { The Sanitary and Epidemiological Rules and } \\
\text { Regulations, SanPin 2.3.2.1078-2001 }\end{array}$ & Russia & $\begin{array}{l}\text { Salmon, salmon, herring, tuna, } \\
\text { and mackerel }\end{array}$ & 100 & 2001 & $\begin{array}{l}\text { Verkhivker and } \\
\text { Altman (2018) }\end{array}$ \\
\hline $\begin{array}{l}\text { Food Standards Australia New Zealand } \\
\text { (FSANZ) }\end{array}$ & $\begin{array}{l}\text { Australia } \\
\text { New } \\
\text { Zealand }\end{array}$ & $\begin{array}{l}\text { Fish species without high } \\
\text { histidine content and fish } \\
\text { products }\end{array}$ & 200 & 2016 & FSANZ (2016) \\
\hline Food Safety and Standards Authority of India & India & Dried/salted fishery products & 200 & - & Surya et al. (2019) \\
\hline $\begin{array}{l}\text { China National Standards. GB 2733-2015; } \\
\text { National Food Safety Standards for Fresh and } \\
\text { Frozen Animal Aquatic Products }\end{array}$ & China & $\begin{array}{l}\text { Fish species high histidine } \\
\text { content and fish products }\end{array}$ & 200 & 2015 & Mah et al. (2019) \\
\hline $\begin{array}{l}\text { China National Standards. GB 2733-2015; } \\
\text { National Food Safety Standards for Fresh and } \\
\text { Frozen Animal Aquatic Products }\end{array}$ & China & $\begin{array}{l}\text { Fish species with high histamine } \\
\text { content }\end{array}$ & 400 & 2015 & Mah et al. (2019) \\
\hline $\begin{array}{l}\text { The Ministry of Food and Drug Safety } \\
\text { (MFDS) of Korea; Food Code, Notification } \\
\text { No. 2017-57 }\end{array}$ & Korea & $\begin{array}{l}\text { Fish species with high histamine } \\
\text { content and fish products }\end{array}$ & 200 & 2017 & Mah et al. (2019) \\
\hline $\begin{array}{l}\text { The Food Safety Basic Act (Act No. } 48 \text { of } \\
\text { 2003) of Japan }\end{array}$ & Japan & Fish and fishery products & $\begin{array}{l}\text { Not } \\
\text { specified }\end{array}$ & 2003 & FAO/WHO (2018) \\
\hline
\end{tabular}

a UV detector (Juhlin and Shelley, 1966). The interaction between HA and $o$-phthalaldehyde attributes to the color. Ough (1971) applied this method for detecting HA levels in wine samples. However, the sample preparation was time-consuming and wasted because of frequent elution via ion exchange and could only be used as relative routine detection without accurate quantification. Thinlayer chromatography (TLC) was developed to attain higher accuracy (Ienisetea, 1973). Here, samples were mixed with methanol solution, heated, cooled, and filtered for extracting the targeted compounds. The detection's sensitivity was attained at a concentration of about 20 ppm (James and Pan, 1985). Although this method is inexpensive, it was only suitable for the semi-quantitative determination of $\mathrm{HA}$.

Alternatively, gas chromatography (GC) was also used for HA quantitative detection in food products. A comparative study of GC and fluorescence methods was conducted to adjust the official detection technique (Rogers and Staruszkiewicz 1997). Careful consideration of the difference in the results highlighted the advantage of GC. The sensitivity of this analysis protocol was $5 \mathrm{ppm}$ when applied to quantify the HA content of fish samples (Hwang et al., 2003). Besides, the prepared megaspores capillary columns needed to be only a little monitoring, and the MS detector accompanying this equipment provided more efficiency. A previous study by Fernandes et al. (2001) also employed the GC-MS technique to determine amine content, including $\mathrm{HA}$, in beer (. This approach had provided excellent sensitivity and accuracy with a sensitivity of less than $150 \mu \mathrm{g} / \mathrm{L}$ HA detected. But the major drawback of GC was its complicated operation, sample preparation, and relatively higher cost (McNair et al., 2019).

The most potent feasible method in chromatography detection was the HPLC approach. This was also used to 
analyze biogenic amine in foods (Önal, 2007). The HPLC equipment and an MS detector achieved relatively high sensitivity (Yoshida et al., 2012). Since HA is a polar biological amine, the normal phase HPLC method was employed to determine HA content in red wine (Dang et al., 2013) using a small organic compound contacting the silica surface as an aqueous phase. Analytes were detected with MS and UV detectors combining with the diamond hydride column filled with a normal aqueous phase. The wine samples were directly injected into the column of the HPLC machine. The advantages of this method are reproducible, cost-effective, and relatively simple. In a Turkey study, 63 fish samples from different cities were analyzed for biogenic amines concentration by the HPLC method. Total biogenic amines were determined, ranging from 26.6 to $406.6 \mathrm{mg} / \mathrm{kg}$ of HA, and this outcome agreed with the study of Bilgin and Gençcelep (2015). HPLC and capillary electrophoresis diode arrays detection showed excellent results with high precision, accuracy, and reproducibility (Cicero et al., 2020). Recently, an ecofriendly and rapid detection method has been developed using the exiting ultra HPLC approach to analyze HA in fish products. This approach provides more accurate results with a total analysis operation time of only 6 minutes, with a detectable limit of $2.2 \mathrm{ppm}$ (Cicero et al., 2020).

\section{Electrochemistry and electrophoresis techniques}

The development of HA detection methods based on electrochemistry or electrophoresis was pivotal in research and industry practice. These methods are often portable, rapid, and inexpensive. Biosensor and microchip electrophoresis are good examples. The electrochemical biosensor could detect biogenic amines in salted anchovies (Draisci et al., 1998). A platinum electrode was used in the cell. The electrode reaction was catalyzed by the enzyme DAO resulting in hydrogen peroxide formation. This method attained a detection limit at $5 \times 10^{-7} \mathrm{moles} / \mathrm{L}$ of the sample. Compared with ion chromatography, the corresponding amine concentrations retained the same trend in the biosensor detection method, revealing that these biosensors could achieve similar results in measuring amines during the food storage period. This technique provides a measurement of the total content of amines present in samples, reducing the analysis cost, time, and ease of operation (Draisci et al., 1998). An electrochemical biosensor based on gold nanoparticle/manganese dioxide electrode was used for detecting a single drop level at $0.08 \mu \mathrm{M}$. An automatic detection method based on magnetic separation combined with fluorescence was also developed, which can detect $\mathrm{HA}$ at a level much lower than $50 \mathrm{ppm}$, the limit established by the FDA (FDA, 2011; Gagic et al., 2020). The combinations of fluorescence with other techniques have also been used as effective detection methods in HA analysis (Shi et al., 2020; Zhang et al., 2020).

\section{ELISA and other rapid detection methods}

Recently, more rapid methods such as ELISA, biosensors, enzymatic assays, or separation techniques are used in the analysis of HA content in foods (Gagic et al., 2019) as they significantly reduce analyzing time and improve sensitivity. While chromatography methods are powerful in laboratory operation, the rapid method application has advantages in practical terms. Specifically, screening studies require a high capacity for analysis of a significant number of samples. Surya et al. (2019) compared the HPLC and a newly developed biomimetic immunoassay method that employed molecularly imprinted polymer and platinum nanozyme to determine HA content in soy sauce and dried shrimp samples. The results of this study showed the correlation between these measures. ELISA basing rapid method could gain sensitivity of 0-500 ppm detection range between 15 minutes and 2 hours (Surya et al., 2019). In another study, 60 canned tuna samples were analyzed for HA content by the ELISA method (Khezri et al., 2014), and the lowest level of HA was reported at 3.4 ppm. Moyano et al. (2019) has developed a histamine magnetic immune-chromatographic biosensor employing protein gold nanoparticle conjugates for labeling samples. This technique can detect a minimum level of 1.2 to $1.5 \mathrm{mg} / \mathrm{L}$ of $\mathrm{HA}$ in samples. Hungerford and Wu (2012) compared three rapid kits, namely Neogen Veratox ELISA, MaxSignal (Texas) based on enzymatic activity, and LFIC (lateral flow immune chromatography). There were no false-positive or negative samples that occurred. ELISA kit showed a negative logistic curve in the color response with increased analyte concentration, resulting in an increasing linear line in the response detected by enzymatic kits. Although ELISA provided good results, MaxSignal kits were more robust and quicker. On the other hand, the LFIC kit was not quantitative, but it could separate between high and low HA level groups. Collectively, while MaxSignal could be considered an appropriate alternative method for ELISA kit, especially in the screening plan, LFIC performed the quickest and simplest means for classification of fish samples into two groups higher or lower than 50 ppm HA (Verma et al., 2020; Xu et al., 2020).

Many enzymatic assays and rapid test kits termed performance- tested methods (PTM) have been validated and qualified by the Association of Official Analytical Collaboration International-Research Institute (AOAC-RI). These test kits include Biofish-300 HIS, BioSystems Y15 histamine dehydrogenase kit, Bioo Scientific MaxSignal histamine enzymatic assay kit, histamine test, HistaSure ELSIA fast track, Veratox 
quantitative histamine test, and RIDASCREEN histamine (enzymatic) kit (AOAC-RI, 2021). These applications are commercially available and widely used in the food industry because of their rapidity, convenience, accuracy, and economic efficiency (Gone et al., 2018; Lacorn et al., 2019; Salleres et al., 2019; Shimoji et al., 2019; 2020; Tobeña et al., 2020). Table 3 summarizes the commonly used methods for the analysis of HA in foods.

\section{Prevention of HA Formation and Control Strategies}

\section{Control of temperature and time}

Time and temperature controls are considered the most effective prevention measure of HA production in food handling practices (Visciano et al., 2014). Temperature control with a rapid chilling method can inactivate or slow enzyme activities; thereby, limiting HA production (Dalgaard and Emborg, 2009). It is indicated that the increase in temperature and time during food storage resulted in the corresponding increase of bacterial growth (Kerr et al., 2002). Similarly, when the storage temperature increased from $5^{\circ} \mathrm{C}$ to $25^{\circ} \mathrm{C}$, a considerable increase in HA formation was found in tuna samples (Nei, 2014). Another study indicated that storing food between $8^{\circ} \mathrm{C}$ to $20^{\circ} \mathrm{C}$ for $1-4$ days is unsafe for consumption in terms of HA hazards (Guizani et al., 2005). A temperature change was created during storage to investigate the difference in HA concentration in Indian mackerel, and the finding showed the correlation between factors examined (Zare et al., 2013). HA can reach a high concentration before spoilage symptoms were observed because of post mortem proteolysis (Klausen and Huss, 1987). Freezing measures (below $-18^{\circ} \mathrm{C}$ ) could stop bacterial activity in HA production (Hu et al., 2012). DeBeer et al. (2021) suggested a tempering process of the frozen tuna with a temperature from $-3^{\circ} \mathrm{C}$ to $-4^{\circ} \mathrm{C}$ to reduce the thawing time in water and meet the critical limits. Precooking could be a valid control measure in food processing to minimize HA formation. There was no increase in HA concentration found in Tuna samples within 12 hours to 18 hours after being precooked (Adams et al., 2018).

The HACCP program was developed as an excellent food industry approach to assure quality and safety (Pierson, 2012). This approach is recommended to be applied by many food authorities in seafood processing and storage (WHO, 2018; Dalgaard and Emborg, 2009). However, HA-producing bacteria such as Photobacterium phosphoreum can survive at a low temperature below $5^{\circ} \mathrm{C}$ (Kanki et al., 2004). Thus, additional factors, such as bacterial contamination and $\mathrm{pH}$ value, should also be considered in the control strategies.

Table 3. Commonly used detection methods for HA content analysis in foods

\begin{tabular}{|c|c|c|c|}
\hline Detection method & Foods & Location & Reference \\
\hline HPLC & Canned fish & 7 European & Duflos et al., 2019 \\
\hline TLC, ELISA, HPLC & Tuna & 9 countries, Iran, USA & Tao et al. (2011) \\
\hline TLC & $\begin{array}{l}\text { Sardine, mackerel, herring, } \\
\text { anchovies }\end{array}$ & 9 countries & Tao et al. (2011) \\
\hline HPLC, Microbial assay & Salted, dried fish & EU, Turkey & Koral et al. (2013) \\
\hline $\begin{array}{l}\text { Colorimetric histamine dehydrogenase (HDH) } \\
\text { assay, enzyme immunoassay test kits, and HPLC }\end{array}$ & $\begin{array}{l}\text { Raw and canned tuna (in oil and } \\
\text { soup), fish meal }\end{array}$ & Japan & Sato et al. (2005) \\
\hline ELISA kit & $\begin{array}{l}\text { Molluscs } \\
\text { Marine fish }\end{array}$ & $\begin{array}{l}\text { South Africa } \\
\text { Bulgaria }\end{array}$ & $\begin{array}{l}\text { Auerswald et al. (2006) } \\
\text { Bangieva et al. (2020) }\end{array}$ \\
\hline Radioenzymatic HA assay, HPLC & Cheese & USA, Spain & $\begin{array}{l}\text { Chin et al. (1989) } \\
\text { Roig-Sagués et al. (2002) }\end{array}$ \\
\hline $\begin{array}{l}\text { Modified enzymatic histamine method based on } \\
\text { colorimetric assay }\end{array}$ & $\begin{array}{l}\text { Fermented foods (soy sauce, } \\
\text { wine, sauerkraut, salami, and } \\
\text { cheese) }\end{array}$ & Japan & Shimoji et al. (2020) \\
\hline Microbial assay and HPLC & Yogurt, & Turkey & Gezginc et al. (2013) \\
\hline HPLC & Soybean & Taiwan & Kung et al. (2007) \\
\hline HPLC & Salami, Sausages, & Italia & Taylor et al. (1978) \\
\hline Fluorometric method, HPLC, and HPLC-UV & Wine & USA & $\begin{array}{l}\text { Pogorzelski (1992) } \\
\text { Coton et al. (1998) Dang et al. } \\
\text { (2013) Ough (1971) }\end{array}$ \\
\hline HPLC & Kimchi & Taiwan & Tsai et al. (2005) \\
\hline
\end{tabular}




\section{Control of bacterial contamination}

Most of the bacteria producing HA are from the environment, so eliminating such bacterial contamination sources should be the key strategy in hazard prevention. It has also been recognized that the HACCP program brings considerable improvements to food quality (Pierson, 2012). In this case, good hygiene and processing practices contribute to a significant reduction in HA formed in food by minimizing temperature abuse and prevent bacterial contamination. Hwang et al. (2011) investigated the prevalence of these bacteria species in two groups of samples with and without applying HACCP in factories. The significantly lower average level of $\mathrm{HA}$ in the HACCP group indicated the significance of this application. The relationship between hygiene condition in processing or handling and HA production was also clearly shown with significant differences in HA contents in fish fillet investigated in Taiwan (Tsai et al., 2005). On the other hand, rapid detection methods for HA-producing bacteria needs to be considered in practical operation of the food industry (Feng et al., 2016). The application of these methods resulted in a significant reduction in the cost of food processing and storage procedures (Dalgaard and Emborg, 2009; Lehane and Olley, 2000; Prabhakar et al., 2020).

\section{pH adjustment}

Degradation of HA can be another measure in controlling food hazards. Bjornsdottir-Butler et al. (2015) investigated the effect of trisodium phosphate (TSP) on the growth of some bacteria producing HA and suggested the probability of using TSP as a treatment to eliminate HA. Psychrotrophic HA-producing bacteria (HPB), including C. freundii, $H$. alvei, P. damselae, E. aerogenes, R. planticola, and M. morganii isolated from fish tissue, were selected for the investigation. Cocktails of these strains were inoculated in tuna fish infusion broth and incubated for $72 \mathrm{~h}$ at $30^{\circ} \mathrm{C}$ with $\mathrm{pH} 5.5$ and 8.5. HPLC measured HA concentrations while a viable HPB count number was defined by the colony lift hybridization method. The study revealed significant findings as HA production at pH 5.5 medium was significantly greater $(\mathrm{P}<0.001)$ than at $\mathrm{pH} 8.5$ for all strains. However, no significant difference was observed $(\mathrm{P}<0.001)$ in the tested bacterial strain growth. Treated samples were measured at significantly higher $\mathrm{pH}$ values than corresponding control sample figures over the storage period. More importantly, HA production in samples treated by phosphate was substantially lower than that in control samples. The findings of this study reveal that $\mathrm{pH}$ is also an option to prevent HA food hazards. Although this study first examined the phosphate treatment for fresh fishes, further investigation on the substance's food safety is necessary.

\section{Other HA control and prevention measures}

Conventional processing methods like salting, drying, smoking, canning, and freezing are not appropriate for HA reduction (Feng et al., 2016; Hwang et al., 2011; Taylor et al., 1989). Although bacterial contamination can be minimized or eliminated by canning or salting, HA residue cannot be destroyed (Lehane and Olley, 2000). Salting treatment alone cannot be an effective measure to prevent HA production (Koral et al., 2013). A vacuum-packed approach with Rosmarinus officinalis treatment was applied on swordfish steaks to evaluate sample shelf-life extension during a 16-day storage period. A significant difference in HA levels was recorded between the control and the treated samples at the end of the storage period with HA concentrations within the limit levels established by FDA (50 ppm) or EU regulations (200 ppm) (Anastasio et al., 2014). Cleide et al. (2021) recently found that salt concentration and ripening temperature during cheese processing could reduce the HA formation ability of Lentilactobacillus parabucheri KUH8. Hence, these factors can be applied as control measures to prevent HA production. Kung et al. (2016) examined the capacity of Bacillus polymyxa to degrade HA formed in processed fish products. A significant reduction in HA content was observed in samples tested, and this bacteria could also be utilized as an additional measure to control HA content in processing fermented fish.

\section{Conclusion}

In recent years, the presence of HA in food and incidence related to HA poisoning are increasing. HA hazards are present in varying food sources throughout the world. Although HA poisoning is a mild disease, HA content can be considered a safety indicator for the food processing practice. Several regulatory agencies have actively revised and adjusted their relevant regulations for better food safety. It could be essential for other food regulators to consider existing technologies and available data to change or establish original rules accordingly. Effective and rapid detection methods with affordable operation costs should be applied in HA content assessment and regulation establishments. On the other hand, global warming because of climate change impacting the surrounding environment and the population increase leads to higher food contamination risks. It is necessary to introduce proper mitigation measures to good manufacturing practices, quality control programs, and advanced food processing technologies to apply in the food production system concerning this hazard. The development of novel approaches based on current scientific knowledge and available data in HA control and prevention measures will be vital and can significantly contribute to human health protection and prevention of HA content 
occurring in the food supply chain. Furthermore, other foods rather than fishery products should also be checked for HA limitations in food legislation.

\section{Conflict of interests}

The authors declare no conflicts of interest.

\section{References}

Adams, F., Nolte, F., Colton, J., De Beer, J. and Weddig, L., 2018. Precooking as a control for histamine formation during the processing of tuna: an industrial process validation. Journal of Food Protection 81: 444-455. https://doi.org/10.4315/0362-028X. JFP-17-276

Anastasio, A., Marrone, R., Chirollo, C., Smaldone, G., Attouchi, M., Adamo, P., et al. 2014. Swordfish steaks vacuum-packed with Rosmarinus officinalis. Italian Journal of Food Science 26: 390397. It is available from: https://www.proquest.com/openview/ f8728b9d66096a57490b9f4a075c01f1/1?pq-origsite=gscholar\& $\mathrm{cbl}=406340$

Ando, T., Kashiwakura, J.-i., Itoh-Nagato, N., Yamashita, H., Baba, M., Kawakami, Y., et al. 2017. Histamine-releasing factor enhances food allergy. The Journal of clinical investigation 127: 4541-4553. https://doi.org/10.1172/jci96525

Association of Official Analytical Collaboration InternationalResearch Institute (AOAC-RI), 2021. PTM validated methods. Available at: https://members.aoac.org/AOAC/PTM_Validated_ Methods.aspx

Auerswald, L., Morren, C. and Lopata, A.L., 2006. Histamine levels in seventeen species of fresh and processed South African seafood. Food Chemistry 98: 231-239. https://doi.org/10.1016/j. foodchem.2005.05.071

Bangieva, D., Stratev, D. and Stoyanchev, T., 2020. Histamine level in freshwater and marine fish sold in Bulgarian markets. Journal of food quality and hazards control 7: 196-199. https://doi. org/10.18502/jfqhc.7.4.4848

Bartholomew, B.A., Berry, P., Rodhouse, J.C., Gilbert, R. and Murray, C., 1987. Scombrotoxic fish poisoning in Britain: features of over 250 suspected incidents from 1976 to 1986. Epidemiology \& Infection 99: 775-782. https://doi.org/10.1017/ s0950268800066632

Bilgin, B. and Gençcelep, H., 2015. Determination of biogenic amines in fish products. Food science and biotechnology 24: 1907-1913. https://doi.org/10.1007/s10068-015-0251-4.

Bjornsdottir-Butler, K., Green, D.P., Bolton, G.E. and McClellanGreen, P.D., 2015. Control of histamine-producing bacteria and histamine formation in fish muscle by trisodium phosphate. Journal of Food Science 80: M1253-M1258. https://doi. org/10.1111/1750-3841.12875

Bodmer, S., Imark, C. and Kneubühl, M., 1999. Biogenic amines in foods: histamine and food processing. Inflammation research 48: 296-300. https://doi.org/10.1007/s000110050463
Cicero, A., Galluzzo, F.G., Cammilleri, G., Pulvirenti, A., Giangrosso, G., Macaluso, A., et al. 2020. Development of a rapid and ecofriendly UHPLC analytical method for the detection of histamine in fish products. International Journal of Environmental Research and Public Health 17: 7453. https://doi.org/10.3390/ijerph17207453

Cleide, O.d.A., Castro-Mejía, J.L., Krych, L. and Rattray, F.P., 2021. Histamine-forming ability of Lentilactobacillus parabucheri in reduced salt cheddar cheese. Food Microbiology 98: 103789. https://doi.org/103789.10.1016/j.fm.2021.103789

Colombo, F.M., Cattaneo, P., Confalonieri, E. and Bernardi, C., 2018. Histamine food poisonings: a systematic review and meta-analysis. Critical reviews in food science and nutrition 58: 1131-1151. https://doi.org/10.1080/10408398.2016.1242476

Comas-Basté, O., Latorre-Moratalla, M.L., Sánchez-Pérez, S., Veciana-Nogués, M.T. and del Carmen Vidal-Carou, M., 2019. Histamine and other biogenic amines in food. From scombroid poisoning to histamine intolerance, Biogenic Amines. Charalampos Proestos, IntechOpen. https://doi.org/10.5772/ intechopen.84333

Comas-Basté, O., Sánchez-Pérez, S., Veciana-Nogués, M.T., LatorreMoratalla, M. and Vidal-Carou, M.d.C., 2020. Histamine intolerance: the current state of the art. Biomolecules 10: 1181. https:// doi.org/10.5772/intechopen.84333

Coton, E., Rollan, G., Bertrand, A. and Lonvaud-Funel, A., 1998. Histamine-producing lactic acid bacteria in wines: early detection, frequency, and distribution. American Journal of Enology and Viticulture 49: 199-204. It is available from: https://www. ajevonline.org/content/49/2/199

Chaidoutis, E., Migdanis, A., Keramydas, D. and Papalexis, P., 2019. Biogenic amines in food as a public health concern. An outline of histamine food poisoning. Archives of Hellenic Medicine/ Arheia Ellenikes Iatrikes 36: 419-425.

Chen, H.C., Kung, H.F., Chen, W.C., Lin, W.F., Hwang, D.F., Lee, Y.C., et al. 2008. Determination of histamine and histamine-forming bacteria in tuna dumpling implicated in a food-borne poisoning. Food Chemistry 106: 612. https://doi. org/10.1016/j.foodchem.2007.06.020

Chin, K., Garriga, M. and Metcalfe, D., 1989. The histamine content of oriental foods. Food and chemical toxicology 27: 283-287. https://doi.org/10.1016/0278-6915(89)90129-4

Chomchai, S. and Chomchai, C., 2018. Histamine poisoning from insect consumption: an outbreak investigation from Thailand. Clinical Toxicology 56: 126-131. https://doi.org/10.1080/15563 650.2017.134.9320

Chung, S.P., 2019. Scombroid fish poisoning and histamine food poisoning. Journal of the Korean Society of Clinical Toxicology 17: 1-6. https://doi.org/10.22537/jksct.17.1.1

Dalgaard, P. and Emborg, J., 2009. Histamine fish poisoning-new information to control a common seafood safety issue, Foodborne Pathogens. Elsevier, pp. 1140-1160. https://doi.org/ 10.1533/9781845696337.3.1140

Dang, A., Pesek, J.J. and Matyska, M.T., 2013. The use of aqueous normal phase chromatography as an analytical tool for food analysis: determination of histamine as a model system. Food Chemistry 141: 4226-4230. https://doi.org/10.1016/j.foodchem.2013.06.005 
Dasgupta, D., 2020. Histamine poisoning by bacteria. International Journal of Current Microbiology and Applied Sciences 9: 34573458. https://doi.org/10.20546/ijcmas.2020.908.400

DeBeer, J., Nolte, F., Lord, C.W. and Colley, J., 2021. Tempering large tuna prior to thawing to minimize histamine formation. Food Protection Trends 41: 38-45. https://doi. org/10.4315/1541-9576-41.1.36

Del Rio, B., Redruello, B., Linares, D.M., Ladero, V., Fernandez, M., Martin, M.C., et al. 2017. The dietary biogenic amines tyramine and histamine show synergistic toxicity towards intestinal cells in culture. Food Chemistry 218: 249-255. https://doi. org/10.1016/j.foodchem.2016.09.046

Dewaal, C.S., Hicks, G., Barlow, K., Alderton, L. and Vegosen, L., 2006. Foods associated with foodborne illness outbreaks from 1990 through 2003. Food Protection Trends 26: 466-473. It is available from: https://www.foodprotection.org/upl/downloads/journal-archive/food-protection-trends-2006-volume-26issue-7.pdf

Draisci, R., Volpe, G., Lucentini, L., Cecilia, A., Federico, R. and Palleschi, G., 1998. Determination of biogenic amines with an electrochemical biosensor and its application to salted anchovies. Food Chemistry 62: 225-232. https://doi.org/10.1016/ s0308-8146(97)00167-2

Duflos, G., Inglebert, G., Himber, C., Degremont, S., Lombard, B. and Brisabois, A., 2019. Validation of standard method EN ISO 19343 for the detection and quantification of histamine in fish and fishery products using high-performance liquid chromatography. International Journal of Food Microbiology 288: 97-101. https://doi.org/10.1016/j.ijfoodmicro.2018.07.023

Durak-Dados, A., Michalski, M. and Osek, J., 2020. Histamine and other biogenic amines in food. Journal of Veterinary Research 64: 281-288. https://doi.org/10.2478/jvetres-2020-0029

European Food Safety Authority (EFSA), 2011. Scientific opinion on risk based control of biogenic amine formation in fermented foods. Available from: https://doi.org/10.2903/j.efsa.2011.2393

European Food Safety Authority (EFSA), 2017. Assessment of the incidents of histamine intoxication in some EU countries. Available from: https://doi.org/10.2903/sp.efsa.2017.EN-1301

European Food Safety Authority (EFSA), 2018. The European Union summary report on trends and sources of zoonoses, zoonotic agents and food-borne outbreaks in 2017. Available from: https://doi.org/10.2903/j.efsa.2010.1496

Ekici, K. and Omer, A.K., 2018. The determination of some biogenic amines in Turkish fermented sausages consumed in Van. Toxicology Reports 5: 639-643. https://doi.org/10.1016/j.toxrep.2018.05.008

EU Commission Regulation, 2013. No 1019/2013 of 23 October 2013 amending Annex I to Regulation (EC) No 2073/2005 as regards histamine in fishery products. Available from: http:// data.europa.eu/eli/reg/2013/1019/oj

Food and Agriculture Organization/World Health Organization (FAO/WHO), 2018. Histamine in salmonids: joint FAO. WHO, Geneva, Switzerland. Available from: http://www.fao.org/3/ CA1207EN/ca1207en.pdf

Fariñas Cabrero, M.A., Berbel Hernández, C., Allué Tango, M., Díez Hillera, M. and Herrero Marcos, J.A., 2015. [Outbreak due to butterfish consumption: keriorrhea and histamine poisoning].
Revista espanola de salud publica 89: 99-105. https://doi. org/10.4321/S1135-57272015000100011

Food and Drug Administration (FDA), 2020. Outbreak investigation of scombrotoxin fish poisoning: yellowfin/ahi tuna (November 2019). Available from: https://www.fda.gov/ food/outbreaks-foodborne-illness/outbreak-investigationscombrotoxin-fish-poisoning-yellowfinahi-tuna-november2019

Food and Drug Administration (FDA), 2011. FDA fish and fishery products hazards and controls guidance. Rockville, MD: US Department of Health and Human Services, Food and Drug Administration. Available from: https://www.fda.gov/ food/seafood-guidance-documents-regulatory-information/ fish-and-fishery-products-hazards-and-controls

Food and Drug Administration (FDA), 2019. Fish and fishery products hazards and controls guidance. Fourth ed. Food and Drug Administration. Available from: https://www.fda.gov/ media/80637/download

Feng, C., Teuber, S. and Gershwin, M.E., 2016. Histamine (scombroid) fish poisoning: a comprehensive review. Clinical reviews in allergy \& immunology 50: 64-69. https://doi.org/10.1007/ s12016-015-8467-x

Fernandes, J., Judas, I., Oliveira, M., Ferreira, I.O. and Ferreira, M., 2001. A GC-MS method for quantitation of histamine and other biogenic amines in beer. Chromatographia 53: S327-S331. https://doi.org/10.1007/bf02490351

Food Standards Australia New Zealand (FSANZ), 2009. Australia New Zealand food standards code-standard 2. Available from: https://www.legislation.gov.au/Details/F2011C00569

Food Standards Australia New Zealand (FSANZ), 2016. Imported food risk statement fish and fish products from the families specified and histamine. Available from: https://www.foodstandards.gov.au/consumer/importedfoods/Documents/Fish\%20 and\%20fish\%20products\%20and\%20histamine.pdf

Gagic, M., Jamroz, E., Krizkova, S., Milosavljevic, V., Kopel, P. and Adam, V., 2019. Current trends in detection of histamine in food and beverages. Journal of Agricultural and Food Chemistry 67: 773-783. https://doi.org/10.1021/acs.jafc.8b05515

Gagic, M., Nejdl, L., Xhaxhiu, K., Cernei, N., Zitka, O., Jamroz, E., et al.2020. Fully automated process for histamine detection based on magnetic separation and fluorescence detection. Talanta 212: 120789. https://doi.org/10.1016/j.talanta.2020.120789

Gardini, F., Martuscelli, M., Caruso, M.C., Galgano, F., Crudele, M.A., Favati, F., et al. 2001. Effects of pH, temperature and $\mathrm{NaCl}$ concentration on the growth kinetics, proteolytic activity and biogenic amine production of Enterococcus faecalis. International Journal of Food Microbiology 64: 105-117. https://doi.org/10.1016/S0168-1605(00)00445-1

Gellert, G.A., Ralls, J., Brown, C., Huston, J. and Merryman, R., 1992. Scombroid fish poisoning. Underreporting and prevention among noncommercial recreational fishers. Western Journal of Medicine 157: 645-647.

Gezginc, Y., Akyol, I., Kuley, E. and Özogul, F., 2013. Biogenic amines formation in Streptococcus thermophilus isolated from homemade natural yogurt. Food Chemistry 138: 655-662. https://doi.org/10.1016/j.foodchem.2012.10.138 
Gone, S., Kosa, N., Krebs, J., Hungerford, J., Trucksess, M. and DeWitt, C., 2018. Validation study of $\mathrm{MaxSignal}^{\circledR}$ histamine enzymatic assay for the detection of histamine in fish/seafood. Journal of AOAC International 101: 783-792. https://doi. org/10.5740/jaoacint.17-0289

Guizani, N., Al-Busaidy, M.A., Al-Belushi, I.M., Mothershaw, A. and Rahman, M.S., 2005. The effect of storage temperature on histamine production and the freshness of yellowfin tuna (Thunnus albacares). Food research international 38: 215-222. https://doi. org/10.1016/j.foodres.2004.09.011

Hajeb, P. and Selamat, J., 2012. A contemporary review of seafood allergy. Clinical reviews in allergy \& immunology 42: 365-385. https://doi.org/10.1007/s12016-011-8284-9

Harmelin, Y., Hubiche, T., Pharaon, M. and Del Giudice, P., 2018. [Three cases of scombroid poisoning]. Ann Dermatol Venereol 145: 29-32. https://doi.org/1016/j.annder.2017.07.007

Hattori, Y. and Seifert, R., 2017. Histamine and histamine receptors in health and disease. Springer. p. 241. https://doi.org/10.1007/ 978-3-319-58194-1

Hu, Y., Huang, Z., Li, J. and Yang, H., 2012. Concentrations of biogenic amines in fish, squid and octopus and their changes during storage. Food Chemistry 135: 2604-2611. https://doi. org/10.1016/j.foodchem.2012.06.121

Hungerford, J. and Wu, W.-H., 2012. Comparison study of three rapid test kits for histamine in fish: BiooScientific MaxSignal enzymatic assay, Neogen Veratox ELISA, and the Neogen Reveal Histamine Screening test. Food Control 25: 448-457. https:// doi.org/10.1016/j.foodcont.2011.11.007

Hungerford, J.M., 2010. Scombroid poisoning: a review. Toxicon 56: 231-243. https://doi.org/10.1016/j.toxicon.2010.02.006

Huss, H.H., Reilly, A. and Embarek, P.K.B., 2000. Prevention and control of hazards in seafood. Food Control 11: 149-156. https://doi.org/10.1016/S0956-7135(99)00087-0

Hwang, B.-S., Wang, J.-T. and Choong, Y.-M., 2003. A rapid gas chromatographic method for the determination of histamine in fish and fish products. Food Chemistry 82: 329-334. https://doi. org/10.1016/s0308-8146(03)00005-0

Hwang, C.-C., Kung, H.-F., Lin, C.-S., Hwang, D.-F. and Tsai, Y.-H., 2011. Bacteriological quality and histamine-forming bacteria associated with fish meats and environments in HACCP and non-HACCP fish processing factories. Food Control 22: 16571662. https://doi.org/10.1016/j.foodcont.2011.03.025

Hwang, C.-C., Tseng, P.-H., Lee, Y.-C., Kung, H.-F., Huang, C.-Y., Chen, H.-C., et al. 2019. Determination of histamine in Japanese Spanish mackerel (Scomberomorus niphonius) meat implicated in a foodborne poisoning. Journal of food protection 82: 1643-1649. https://doi.org/10.4315/0362-028x.jfp-19-111

Ibranji, A., Nikolla, E., Loloci, G. and Mingomataj, E., 2015. A case report on transitory histamine intolerance from strawberry intake in a 15-month-old child with acute gastroenteritis. Clinical and Translational Allergy 5: P61. https://doi. org/10.1186/2045-7022-5-S3-P61

Ienisetea, C., 1973. Significance and detection of histamine in food. Microbiological Safety of Food: 327-343.

Ijomah, P., Clifford, M., Walker, R., Wright, J., Hardy, R. and Murray, C., 1991. The importance of endogenous histamine relative to dietary histamine in the aetiology of scombrotoxicosis. Food Additives \& Contaminants 8: 531-542. https://doi. org/10.1080/02652039109374005

Joenputri, N. and Suryana, K., 2020. Histamine toxicity resembles an allergic reaction: a case report. International Journal of Science and Research 9: 1208-1210. https://doi.org/10.21275/ ART20204295

Joosten, H., 1988. Conditions allowing the formation of biogenic amines in cheese. Netherlands Milk and Dairy Journal 42: 3-24. It is available from: https://edepot.wur.nl/201867

Joosten, H. and Northolt, M., 1989. Detection, growth, and amine-producing capacity of lactobacilli in cheese. Applied and environmental microbiology 55: 2356-2359. https://doi. org/10.1128/aem.55.9.2356-2359.1989

Juhlin, L. and Shelley, W.B., 1966. Detection of histamine by a new fluorescent o-phthalaldehyde stain. Journal of Histochemistry \& Cytochemistry 14: 525-528. https://doi.org/10.1177/14.7.525

Kanki, M., Yoda, T., Ishibashi, M. and Tsukamoto, T., 2004. Photobacterium phosphoreum caused a histamine fish poisoning incident. International Journal of Food Microbiology 92: 79-87. https://doi.org/10.1016/j.ijfoodmicro.2003.08.019

Kang, C.R., Kim, Y.Y., Lee, J.I., Joo, H.D., Jung, S.W. and Cho, S.-I., 2018. An outbreak of scombroid fish poisoning associated with consumption of yellowtail fish in Seoul, Korea. Journal of Korean medical science 33: e235. https://doi.org/10.3346/jkms.2018.33.e235

Kerr, M., Lawicki, P., Aguirre, S. and Rayner, C., 2002. Effect of storage conditions on histamine formation in fresh and canned tuna. Victoria, Australia: Public Health Divi Victor Gover Depart Human. p. 5-20.

Klausen, N.K. and Huss, H.H., 1987. Growth and histamine production by Morganella morganii under various temperature conditions. International Journal of Food Microbiology 5: 147-156. https://doi.org/10.1016/0168-1605(87)90032-8

Konakovsky, V., Focke, M., Hoffmann-Sommergruber, K., Schmid, R., Scheiner, O., Moser, P., et al. 2011. Levels of histamine and other biogenic amines in high-quality red wines. Food Additives and Contaminants 28: 408-416. https://doi.org/10.10 80/19440049.2010.551421

Koral, S., Tufan, B., Ščavničar, A., Kočar, D., Pompe, M. and Köse, S., 2013. Investigation of the contents of biogenic amines and some food safety parameters of various commercially salted fish products. Food Control 32: 597-606. https://doi.org/10.1016/j. foodcont.2013.01.043

Kovacova-Hanuskova, E., Buday, T., Gavliakova, S. and Plevkova, J., 2015. Histamine, histamine intoxication and intolerance. Allergologia et immunopathologia 43: 498-506. https://doi. org/10.1016/j.aller.2015.05.001

Kung, H.-F., Lee, Y.-C., Huang, Y.-R., Lin, W.-F., Lin, C.-M., Chen, W.-C. and Tsai, Y.-H., 2010. Biogenic amines content, histamine-forming bacteria, and adulteration of pork and poultry in tuna dumpling products. Food Control 21: 977-982. https://doi. org/10.1016/j.foodcont.2009.12.011

Kung, H.-F., Tsai, Y.-H. and Wei, C.-I., 2007. Histamine and other biogenic amines and histamine-forming bacteria in miso products. Food Chemistry 101: 351-356. https://doi.org/10.1016/j. foodchem.2005.12.057 
Kung, H.F., Lee, Y.C., Tseng, Y.L., Huang, Y.L., Chen, T.Y. and Tsai, Y.H., 2016. Degradation of histamine in salted fish product by halotolerant Bacillus polymyxa. Journal of Food Safety 36: 325-331. https://doi.org/10.1111/jfs.12247

Khezri, M., Hosseininia, S.A.R. and Kamani, M.H., 2014. Determination of histamine in canned tuna using ELISA method. Trends in Life Sciences 3. Available from: https://profdoc.um. ac.ir/paper-abstract-1045527.html

Lacorn, M., Garrido, G., Reck, B., Sutterlüti, M., Lindeke, S. and Meinhardt, P., 2019. Validation of the R-Biopharm AG RIDASCREEN ${ }^{\circ}$ histamine (enzymatic) kit: AOAC performance tested methods SM 031901. Journal of AOAC International 102: 1472-1491. https://doi.org/10.1093/jaoac/102.5.1472

Ladero, V., Calles-Enríquez, M., Fernández, M. and A Alvarez, M., 2010. Toxicological effects of dietary biogenic amines. Current Nutrition \& Food Science 6: 145-156. https://doi. org/10.2174/157340110791233256

Ladero, V., Linares, D.M., Fernández, M. and Alvarez, M.A., 2008. Real time quantitative PCR detection of histamine-producing lactic acid bacteria in cheese: relation with histamine content. Food research international 41: 1015-1019. https://doi. org/10.1016/j.foodres.2008.08.001

Lehane, L. and Olley, J., 2000. Histamine fish poisoning revisited. International Journal of Food Microbiology 58: 1-37. https:// doi.org/10.1016/s0168-1605(00)00296-8

Leonard, B., 2011. Fish and fishery products: hazards and controls guidance. DIANE publishing.

Leuschner, R.G., Heidel, M. and Hammes, W.P., 1998. Histamine and tyramine degradation by food fermenting microorganisms. International Journal of Food Microbiology 39: 1-10. https:// doi.org/10.1016/s0168-1605(97)00109-8

Linares, D.M., Martín, M., Ladero, V., Alvarez, M.A. and Fernández, M., 2011. Biogenic amines in dairy products. Critical reviews in food science and nutrition 51: 691-703. https://doi. org/10.1080/10408398.2011.582813

Mah, J.-H., Park, Y.K., Jin, Y.H., Lee, J.-H. and Hwang, H.-J., 2019. Bacterial production and control of biogenic amines in Asian fermented soybean foods. Foods 8: 85. https://doi.org/10.3390/ foods 8020085

Maintz, L. and Novak, N., 2007. Histamine and histamine intolerance. The American journal of clinical nutrition 85: 1185-1196. https://doi.org/10.1093/ajcn/85.5.1185

Masson, F., Talon, R. and Montel, M.-C., 1996. Histamine and tyramine production by bacteria from meat products. International Journal of Food Microbiology 32: 199-207. https://doi.org/ 10.1016/0168-1605(96)01104-X

McLaughlin, J. and Castrodale, L., 2019. Seven patients diagnosed with scombroid poisoning-Alaska, summer 2019. Headache 43: 3.

McNair, H.M., Miller, J.M. and Snow, N.H., 2019. Basic gas chromatography. John Wiley \& Sons. https://doi.org/10.1002/ 9781119450795

Mercogliano, R. and Santonicola, S., 2019. Scombroid fish poisoning: factors influencing the production of histamine in tuna supply chain. A review. LWT 114: 108374. https://doi.org/10.1016/j. lwt.2019.108374.
Møller, C.d.A., Ücok, E. and Rattray, F., 2020. Histamine forming behaviour of bacterial isolates from aged cheese. Food Research International 128: 108719. https://doi.org/10.1016/j. foodres.2019.108719

Morrow, J.D., Margolies, G.R., Rowland, J. and Roberts, L.J., 1991. Evidence that histamine is the causative toxin of scombroid-fish poisoning. New England Journal of Medicine 324: 716-720. https://doi.org/10.1056/NEJM199103143241102

Morroy, G., Ooms, D., Jansen, H.J., Dijkstra, J., van DrunenKamp, K.J. and Batstra-Blokpoel, J., 2018. [Fish-caused illness: notify food-related outbreaks to the Municipal Health Services]. Nederlands tijdschrift voor geneeskunde 162: D2155.

Moyano, A., Salvador, M., Martínez-García, J.C., Socoliuc, V., Vékás, L., Peddis, D., et al. 2019. Magnetic immunochromatographic test for histamine detection in wine. Analytical and Bioanalytical Chemistry 411: 6615-6624. https://doi. org/10.1007/s00216-019-02031-6

Nei, D., 2014. Evaluation of non-bacterial factors contributing to histamine accumulation in fish fillets. Food Control 35: 142145. https://doi.org/10.1016/j.foodcont.2013.06.037

O’Mahony, L., Akdis, M. and Akdis, C.A., 2011. Regulation of the immune response and inflammation by histamine and histamine receptors. Journal of Allergy and Clinical Immunology 128: 1153-1162. https://doi.org/10.1016/j.jaci.2011.06.051

Omura, Y., Price, R. and Olcott, H., 1978. Histamine - forming bacteria isolated from spoiled skipjack tuna and jack mackerel. Journal of Food Science 43: 1779-1781. https://doi. org/10.1111/j.1365-2621.1978.tb07412.x

Önal, A., 2007. Current analytical methods for the determination of biogenic amines in foods. Food Chemistry 103: 1475-1486. https://doi.org/10.1016/j.foodchem.2006.08.028

Ough, C.S., 1971. Measurement of histamine in California wines. Journal of Agricultural and Food Chemistry 19: 241-244. https://doi.org/10.1021/jf60174a038

Pan, B.S. and James, D., 1985. Histamine in marine products: production by bacteria, measurement and prediction of formation. Food \& Agriculture Organization.

Petrovic, J., Babic, J., Jaksic, S., Kartalovic, B., Ljubojevic, D. and Cirkovic, M., 2016. Fish product-borne histamine intoxication outbreak and survey of imported fish and fish products in Serbia. Journal of Food Protection 79: 90-94. https://doi. org/10.4315/0362-028x.jfp-15-190

Pierson, M.D., 2012. HACCP: principles and applications. Springer Science \& Business Media. https://doi. org/10.1007/978-1-4684-8818-0

Pogorzelski, E., 1992. Studies on the formation of histamine in must and wines from elderberry fruit. Journal of the Science of Food and Agriculture 60: 239-244. https://doi.org/10.1002/ jsfa.2740600212

Prabhakar, P.K., Vatsa, S., Srivastav, P.P. and Pathak, S.S., 2020. A comprehensive review on freshness of fish and assessment: analytical methods and recent innovations. Food research international 133: 109157. https://doi.org/10.1016/j. foodres.2020.109157

Rogers, P.L. and Staruszkiewicz, W., 1997. Gas chromatographic method for putrescine and cadaverine in canned tuna and 
mahimahi and fluorometric method for histamine (minor modification of AOAC Official Method 977.13): collaborative study. Journal of AOAC International 80: 591-602. https://doi. org/10.1093/jaoac/80.3.591

Roig-Sagués, A.X., Molina, A.P. and Hernández-Herrero, M., 2002. Histamine and tyramine-forming microorganisms in Spanish traditional cheeses. European Food Research and Technology 215: 96-100. https://doi.org/10.1007/s00217-002-0521-2

Salleres, S., González, I., Arantzamendi, A., González, R., Maza, S., Jaureguibeitia, A., et al. 2016. Validation of the Biofish-300 HIS enzymatic biosensor for the detection of histamine in fishery products. Journal of AOAC International 99: 1338-1355. https://doi.org/10.5740/jaoacint.16-0180

Şanll, T. and Şenel, E., 2015. Formation of biogenic amines in cheese, processing and impact on active components in food. Elsevier, pp. 223-230. https://doi.org/10.1016/ B978-0-12-404.699-3.00027-5

Sato, T., Horiuchi, T. and Nishimura, I., 2005. Simple and rapid determination of histamine in food using a new histamine dehydrogenase from Rhizobium sp. Analytical biochemistry 346: 320-326. https://doi.org/10.1016/j.ab.2005.09.005

Schirone, M., Visciano, P., Tofalo, R. and Suzzi, G., 2016. Histamine food poisoning, histamine and histamine receptors in health and disease. Springer, pp. 217-235. https://doi. org/10.1007/164_2016_54

Shi, R., Feng, S., Park, C.Y., Park, K.Y., Song, J., Park, J.P., et al. 2020. Fluorescence detection of histamine based on specific binding bioreceptors and carbon quantum dots. Biosensors and Bioelectronics 167: 112519. https://doi.org/10.1016/j. bios.2020.112519

Shimoji, K., Bakke, M., Hungerford, J.M., Mireles DeWitt, C.A. and Köse, S., 2019. Validation study of histamine test for the determination of histamine in selected fish products. Journal of AOAC International 102: 164-180. https://doi.org/10.4315/JFP-20-082

Shimoji, K., Isono, E. and Bakke, M., 2020. Modified enzymatic assays for the determination of histamine in fermented foods. Journal of Food Protection 83: 1430-1437.

Silva, C.M. and Glória, M.B.A., 2002. Bioactive amines in chicken breast and thigh after slaughter and during storage at $4 \pm 1 \mathrm{C}$ and in chicken-based meat products. Food Chemistry 78: 241-248. https://doi.org/10.1016/S0308-8146(01)00404-6

Smith, T.A., 1981. Amines in food. Food Chemistry 6: 169-200. https://doi.org/10.1016/0308-8146(81)90008-X

Stommel, E.W., 2007. Scombroid fish poisoning, foodborne diseases. Springer, pp. 375-381. https://doi.org/10.1007/978-1-59745501-5_14

Stratton, J.E., Hutkins, R.W., Sumner, S.S. and Taylor, S.L., 1992. Histamine and histamine-producing bacteria in retail Swiss and low-salt cheeses. Journal of Food Protection 55: 435-439. https://doi.org/10.4315/0362-028X-55.6.435

Sumner, S.S., Speckhard, M.W., Somers, E.B. and Taylor, S.L., 1985. Isolation of histamine-producing Lactobacillus buchneri from Swiss cheese implicated in a food poisoning outbreak. Applied and environmental microbiology 50: 1094-1096. https://doi. org/10.1128/AEM.50.4.1094-1096.1985
Surya, T., Sivaraman, B., Alamelu, V., Priyatharshini, A., Arisekar, U. and Sundhar, S., 2019. Rapid methods for histamine detection in fishery products. International Journal of Current Microbiology and Applied Sciences 8: 2035-2046. https://doi.org/10.20546/ ijcmas.2019.803.242

Tao, Z., Sato, M., Yamaguchi, T. and Nakano, T., 2009. Formation and diffusion mechanism of histamine in the muscle of tuna fish. Food Control 20: 923-926. https://doi.org/10.1016/j. foodcont.2009.01.011

Tao, Z., Sato, M., Zhang, H., Yamaguchi, T. and Nakano, T., 2011. A survey of histamine content in seafood sold in markets of nine countries. Food Control 22: 430-432. https://doi.org/10.1016/j. foodcont.2010.09.018

Taylor, S.L., Lieber, E.R. and Leatherwood, M., 1978. A simplified method for histamine analysis of foods 1 . Journal of Food Science 43: 247-250. https://doi.org/10.1111/j.1365-2621.1978. tb09783.x

Taylor, S.L., 1985. Histamine poisoning associated with fish, cheese, and other foods, World Health Organization. https://apps.who. int/iris/handle/10665/66407

Taylor, S.L., Stratton, J.E. and Nordlee, J.A., 1989. Histamine poisoning (scombroid fish poisoning): an allergy-like intoxication. Journal of Toxicology: Clinical Toxicology 27: 225-240. https:// doi.org/10.3109/15563658908994420

Tobeña, A., Dueñas, S. and Boix, M., 2020. Validation Study of BioSystems ${ }^{\circ}$ Y15 histamine dehydrogenase kit for the detection of histamine in fish and fishery products: AOAC performance tested methodSM 072001. Journal of AOAC International. qsaa139. https://doi.org/10.1093/jaoacint/qsaa139

Tsai, Y.-H., Kung, H.-F., Chang, S.-C., Lee, T.-M. and Wei, C.-I., 2007. Histamine formation by histamine-forming bacteria in douchi, a Chinese traditional fermented soybean product. Food Chemistry 103: 1305-1311. https://doi.org/10.1016/j.foodchem.2006.10.036

Tsai, Y.-H., Kung, H.-F., Lin, Q.-L., Hwang, J.-H., Cheng, S.-H., Wei, C.-I. and Hwang, D.-F., 2005. Occurrence of histamine and histamine-forming bacteria in kimchi products in Taiwan. Food Chemistry 90: 635-641. https://doi.org/10.1016/j. foodchem.2004.04.024

Tham, W., Karp, G. and Danielsson-Tham, M.-L., 1990. Histamine formation by enterococci in goat cheese. International Journal of Food Microbiology 11: 225-229. https://doi. org/10.1016/0168-1605(90)90015-W

Tran, Q.H., Nguyen, T.T. and Pham, K.P., 2020. Development of the high sensitivity and selectivity method for the determination of histamine in fish and fish sauce from Vietnam by UPLC-MS/MS. International journal of analytical chemistry 2020. https://doi. org/10.1155/2020/2187646

van Dijken, G.D., Uijttewaal, P.H., Logtenberg, S.J.J. and Sankatsing, S.U.C., 2020. [Scombroid food poisoning among hospital personnel], Nederlands tijdschrift voor geneeskunde. 164 .

Velut, G., Delon, F., Mérigaud, J.P., Tong, C., Duflos, G., Boissan, F., et al. 2019. Histamine food poisoning: a sudden, large outbreak linked to fresh yellowfin tuna from Reunion Island, France, April 2017. Eurosurveillance 24: https://doi.org/10.2807/1560-7917. ES.2019.24.22.1800405 
Verkhivker, Y. and Altman, E., 2018. Influence parameters of storage on process of formation the histamine in fish and fish products. Journal of Water Resources and Ocean Science7: 10-14. https:// doi.org/10.11648/j.wros.20180701.12

Verma, N., Hooda, V., Gahlaut, A., Gothwal, A. and Hooda, V., 2020. Enzymatic biosensors for the quantification of biogenic amines: a literature update. Critical Reviews in Biotechnology 40: 1-14. https://doi.org/10.1080/07388551.2019.1680600

Vidal-Carou, M., Izquierdo-Pulido, M. and Martin-Morro, M., 1990. Histamine and tyramine in meat products: relationship with meat spoilage. Food Chemistry 37: 239-249. https://doi. org/10.1016/0308-8146(90)90104-C

Visciano, P., Schirone, M. and Paparella, A., 2020. An overview of histamine and other biogenic amines in fish and fish products. Foods 9: 1795. https://doi.org/10.3390/foods9121795

Visciano, P., Schirone, M., Tofalo, R. and Suzzi, G., 2014. Histamine poisoning and control measures in fish and fishery products. Frontiers in microbiology 5: 500. https://doi.org/10.3389/ fmicb.2014.00500

World Health Organization (WHO), 1982. Factors contributing to outbreaks of food poisoning. Available from: https://apps.who. int/iris/handle/10665/223935

Xu, L., Zhou, J., Eremin, S., Dias, A.C. and Zhang, X., 2020. Development of ELISA and chemiluminescence enzyme immunoassay for quantification of histamine in drug products and food samples. Analytical and Bioanalytical Chemistry 412: 4739-4747. https://doi.org/10.1007/s00216-020-02730-5

Yoshida, T., Hamada, H., Murakawa, H., Yoshimoto, H., Tobino, T. and Toda, K., 2012. Determination of histamine in seafood by hydrophilic interaction chromatography/tandem mass spectrometry. Analytical sciences 28: 179-179. https://doi. org/10.2116/analsci.28.179

Zare, D., Muhammad, K., Bejo, M.H. and Ghazali, H., 2013. Changes in urocanic acid, histamine, putrescine and cadaverine levels in Indian mackerel (Rastrelliger kanagurta) during storage at different temperatures. Food Chemistry 139: 320-325. https://doi. org/10.1016/j.foodchem.2012.12.040

Zeng, Z., Shen, L., Li, X., Luo, T., Wei, X., Zhang, J., et al. 2014. Disruption of histamine $\mathrm{H} 2$ receptor slows heart failure progression through reducing myocardial apoptosis and fibrosis. Clinical science 127: 435-448. https://doi.org/10.1042/ CS20130716

Zhang, B., Sheng, W., Liu, Y., Huang, N., Zhang, W. and Wang, S., 2020. Multiplexed fluorescence immunoassay combined with magnetic separation using upconversion nanoparticles as multicolor labels for the simultaneous detection of tyramine and histamine in food samples. Analytica Chimica Acta 1130: 117-125. https://doi.org/10.1016/j.aca.2020.07.043 